Grand Valley State University

ScholarWorks@GVSU

Summer 1994

\title{
A Gifted Child's Education Requires Real Dialogue: The Use of Interactive Writing for Collaborative Education
}

Dorothy Ciner Armstrong

Grand Valley State University, armstrod@gvsu.edu

Follow this and additional works at: https://scholarworks.gvsu.edu/coe_articles

Part of the Education Commons

\section{ScholarWorks Citation}

Ciner Armstrong, Dorothy, "A Gifted Child's Education Requires Real Dialogue: The Use of Interactive Writing for Collaborative Education" (1994). Peer Reviewed Articles. 9.

https://scholarworks.gvsu.edu/coe_articles/9

This Article is brought to you for free and open access by the Education at ScholarWorks@GVSU. It has been accepted for inclusion in Peer Reviewed Articles by an authorized administrator of ScholarWorks@GVSU. For more information, please contact scholarworks@gvsu.edu. 


\title{
A Gifted Child's Education Requires Real Dialogue: The Use of Interactive Writing for Collaborative Education
}

\author{
Dorothy Ciner Armstrong \\ Grand Valley State University
}

\begin{abstract}
This paper reports the findings of two studies which compared the responses to using dialogue journals by teachers of the gifted and talented and their students. The purpose of this research was to learn more about the ways that such interaclive writing can enable GT students to collaborate effectively in their own education. Study 1 sought to determine the types of discourse functions teachers used in the journals they kept with their instructor in a graduate practicum and with the GT students they taught in that practicum. They interacted differently with their instructor than with their sludents in ways consistent with their role: they commonly used questions, a controlling behavior, when journaling with students. Study 2 examined whether teachers could vary. their responses to students' journals to make them more collegial and less controlling. Together these studies supported the use of dialogue joumals to promote mutuality in the educational process.
\end{abstract}

Research indicats that gifted and tatented students want to be actively involued in their own education. The research on learning styles confirms the importance gifted and talented student thentselves place on heing able to leam activery and independerilly (Boutinghosse. 1984, Dun \& Griggs, 1985; Dunn \& Price 1980. Price, 1981; Sctuggs \& Mastropieri. 1984: Stewart: 1981): the research on locus of control docu ments the importance that gifted and talented students place on being able? to control or affoct what happeris to and for thern (Carland. 1981; Treehil, 1982. Harty. Atkins, \& Hungale, 1984: Jeter \& Chemivi, 1982: Middleton, Littlefield. \& Lerhrer. 1992; Milgram \& Mitgram. 1975,1976: Passow. 1979. Saureman \& Michael, 1980; Whitmore, 1986: Yong, 1994).

Maker (1082) recommends that "learning envomments for gifted children must (a) be student centered rather than teacher centered, and (b) encourage independence rather than depen dence" (p. 85). The research that directly supports this recommendation for las leacherentered pedagouy (Shore, Comell. Robinson, \& Ward. 1991) resonates with the work of other infuential cducators (e.s. Bruner 1962, 1978; Shor \& Freire, 1987: Vyotsky. 1978) who believe that collaboration between teachers and students is essential for promoting sulicessful learning.

In order for true collaboration of this type to take place. however. teachers need to be willing and able to shed some of the traditional vestments of classroom power. and students need to be willing and able to assume this responsibility effectively. This research explored the potential of dialogue journals to be an effective component of collaborative, student-centered leaming for gifted and talented students.

Dialoxue joumals have been defined as "a written conversation between two persons on a continited basis, about topics of individual (and eventually mutual) interess" (Staton. Shuy, Peyton. \& Reed. 1988, r. 312) In addition to self generation. of topics and intaractive responses, dialogue joumals encourage the use of functional writing, that is, writing for a particular purpose (Shuy, 198\%). If. as Vygotsky (1962) suggests, thoughts represent internal dialogue, then the analysis of personal writings such as those in dialogue joumals should be done by looking at the ways journal responses parallel other types of language usage. Shu (1988) identified 16 language or dis course functions that have been used extensively to analyze response patterns in dialogue journals. Examples of Shuy's discourse funcions include reporting opinions, responding to question lis, complaining, giving directives, and requesting information. These response categories are equally applicable to analyzing diatogue joumals' potential for promoting student teacher collaboration in the classroom.

Studies have been cone to learn more about dialogue jour nals effectiverness in enhancing language development in vari ous purplialions of students: young chitdren (Garcia. 1990: Hall \& Dufy, 1987), elementary (Reed, 1988), middes school (McWhirter. 1990). high shool ard college (Kilagawa \& Kitagawa. 1987: Roderick \& Berman, 1984), hearing-impaired (Wetter \& Conway. 1988: Staton. 1985), bilingual (I Iudelson.

\section{Putting the Research to Use}

Dialogue joumals demonstrably promote communicalion. Teachers in these studies clearly found that joumaling enhanced their ability to communicate to their students about both cognilive art dffective matters. They also found that joumals were an effective way for them to learr from a source they thought to be authoritative. their course instructor. However. if, as Study 2 showed teachers can learm lo participate in jourraling with what Shuy (1987) calli; "shared mutuality" "they can overcome role betwitor and be open to leaming from their stukt th through the journaling process. Only then can il achieve its full potential as a means by which gitted

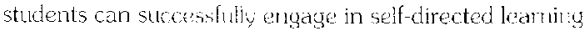
in collaboration with their teachers. 
1989: Peyton, 1900. Peyton \& Seyoum. 1989, Unzua. 1987), Native American (Catho. 1987), mentally retarded ([arley, 1985), learning disalled (Gaustad \& Messenheimer-Young, 1991; McGettigan, 1987: Staton \& Tyler. 1987). These studies document that students representing a broad range of age, ability, and language facility can successfully participate in interactive writing with their teachers.

The only study that was found on the gifted was done by Farley and Farley (1987). Who reported on the match between learning characteristics of the gifted and the use of dialogue journals using a case study of a young gifted child who was maintaining a dialogue fournat with her father as she was beginning to read and write. They reported that

the documented learning styles of the gifted and the characteristics for maintaining dialogue journals are uniquely compatible: gifled children are seen as dynamic communicalors and dialogue joumals are seen as a dynamic approach to communication. (p. 101)

Most studies on the use of dialogue journals have focused on the ability of the process to enhance language development or content mastery (Alwell, 1987; Bailes, Searls, Slobodzian, \& Staton, 1986; Bode, 1989: Dariielson, 1988; I ulwiler, 1987; Garnturell, 1985; Jackson, 1992; Keeft, 1987; Manning \& Manning, 1989: Staton. 1980; Urzua, 1987) and have not studied their pedagogical potential for facilitating a collegial approach to leaming. It is clearly important for gifted sturlents to develop communication skills (Alexander \& Muia, 1982: Dearborn, 1979. Freetill, 1982: Guldberg, Passow, \& Lorge. 1980: Perrone \& Male, 1981), and dialogue journals can contribute to that develomment. However, dialogue journals also promote what Shuv (1987) called shared mutuality: "two people interacting througlt the medium of language" (p. 890) in ways that are ricol bound by traditional terdeder-student status roles. This dimerision of dialogue ioumals is central to their being able to promote a successful collaborative teachinglearning relationship.

\section{Purpose}

Study 1 examined whelher teachers who were using dialogue journals as a component of a student centered, interestbased practicu:n would deviate from traditional teacher-directed roles in their responses both in the journals they kept with their own seminar instructor and in the journals of the students with whom they also joumaled. Based on the findings of Study 1 , Sudy 2 examined whether teachers, when trained with ar alternate model, would avoid using questions, a lypical teacher role behavior, in responding to their students' journals. Also in Study 2, students were asked for their opinions about the value and colliaborative potential of maintaining dialogute journals,

For each of the three consecutive summers of this research. teadkers were trained in the use of dialogue journals as one convenent of their 0 week, university based sumner practicum in gifled education. Students were selected to participate in the 3-week summer prosiram for high-ability students based on similar but not identical criteria. The evidence that they were in the top $5-8 \%$ was documented by a combination of indicators including standardized test achievement test scores and classroom teacher judgments regarding the student's academic ability and motivation.

In Study 1 teachers maintained dialogue joumals with their seminar instructor and with their own class of 15-18 students. In Study 2 teachers and students maintained three way journals. Teachers exchanged journals with both their seminar instructor and a teacher peer. Students exchanged journals with both their classroom teacher and a sludent peer. Together these studies provide information about both teachers' ability to engage students with genuine mutuality and students. ability and interest in sharing journal dialogues.

\section{Study 1}

The purpose of this study was to investigale in what ways teachers who were participating in a program that actively promoted student-centered learning naturally extended these principles in the use of dialogue journals. Did they engage in interactive wriling with their students in ways that were consistent with traditional teacher directed strategies? Would they engage in dialogue journals with shared muluality?

\section{Method}

Subjects. Subjects for this sudy were 11 teachers. 10 of whom were female, and 195 sudents. $56 \%$ male and $11 \%$ female. Sixty-three percent of the students were in Cirates 1 3 , and $37 \%$ were in Grades 47.

Procedure. 'leachers attended a .3-week instructional semi nar prior to the students' 3-week program. During this semi nar, teachers were guided in the development of curriculum units around the interests their class of students had specified on program applications.

During the final week of the semirlar, teachers received training in techniques for using dialogue journals with their students but not in the Shuy discourse functions (1988) that would be used hater in the analysis of the joumal entries. Teachers were expected to maintain dialogue jounals with each of the students in their class as well as with their course instructor (this researcher) linoughoul the 6 weeks of the practicum.

Data Analysis. Teachers', studenis, ard the seminar instructor's journal entries were analyzed for fluency and flex ibility using the 16 discourse functions identified by Shuy (1988). For purroses of analysis, fluency was defined as the number of times a discourse function was used and flexibility as the number of different discourse functions used. The dis course functions were not mulually exclusive, so it was possible for a singles entry to be classified in more than one function For example, in this response a returning teacher is sharing both personal information and predicting:

I have becone much more realistic this summer in predicting the amount of information l can squeeze into 
3 weeks. I don'l iturik I will feel as frustrated labout this as I did last summer].

Prior to doing the analysis, this researcher exclanged samples of the dialogue journal entries with other experienced restidrchers until there was interrater reliability of $p>90$ agrement in classifying the discourse functions. No one involved in the stuky knew of the discourse functions at the time the joumals were done, but the 16 functions accounted for all responses.

\section{Results and Discussion}

In both their personal and classroom journals, all teachers initiated iopics, maintained sustained interactive dialogue on a broad array of topics, and demonstrated their varied use of Shuy's discourse functions. The ways in which they did so. however, showed evidence of role-related responses (see 1 igure 1 ) that were more typical of stereotypical teacher-directed pedagogy than of shared mutuality in the teaching/learning process.

Teachers as models for the uses of language functions. Seven of 11 teachers used at least two more? discourse functions in responding to their students than in their personal journals, two used an equal number, and two used fewer with their own students. Clearly these teachers had intuitively modeled broader use of language functions in the? journals with their students than they had used in their yersonal joumals. This finding was consistent with dackson (1992), who reforted in her analysis of middle school students' responses that "leachers' responses stimulate growth by modeling an appropriate advance in language functions" (p. 56).

One might hypothesize that teachers, as mature communicators, would be expected to use more language functions than their students. I lowever, these same teachers respondexd differently when they were in the role of student in the graduate classroom than they did when they were teachers with their own students. Only 3 of 11 teachers used 11 or more discourse functions in their personal journals. In contrast, 8 teachers used 11 or more language functions in the journals they maintained with their students.

Role-related responses. When leachers were in the role of teacher, their journal entries reflected additional types of stereotypical teacher responses. For example, the teachers used their personal journals to reflect on their praxis:

I keep backing up ny lesson plans because we just don t get as much done as I plan but the pace ferts right for the kids.

\section{Fluency of Discourse Function Use}

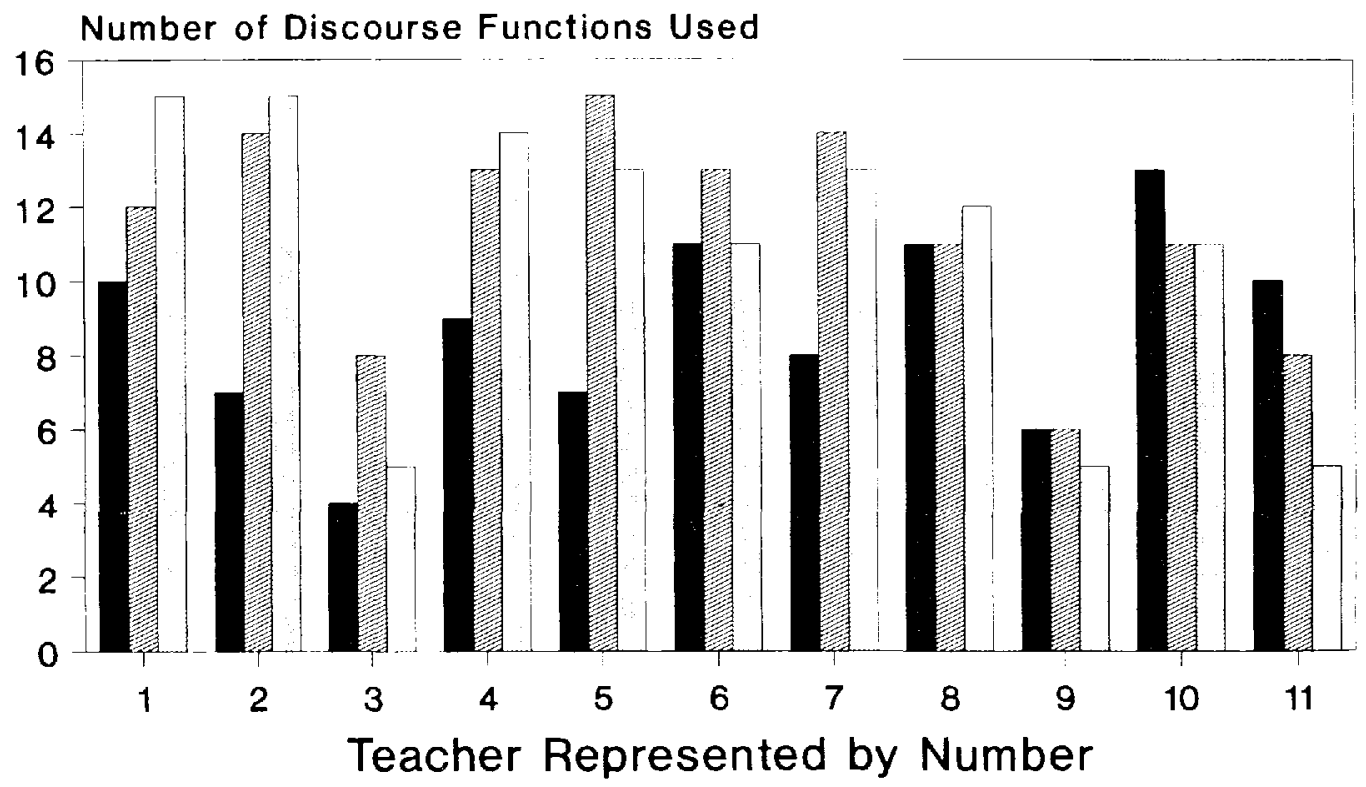

Teachers' Journals

Teachers' Responses Students' Journals 
Thank you for the suggestions! I originally thought of doing activities like you suggested but became sidetracked somentere along the way.

Teachers also saw the journals as a way they could meet their students' individual cognitive and affective needs:

I have one boy that seems so sharp but is so shy and guarded. I don't know if he's enjoying this. Maybe he will share something in his poumal.

I have at stukent named who has torn a paper ftom her joumal and handed it to me on the way out. She is urset that the other kids don't talk to her. I will find a new stalion for her to sit. is very sensitive lowards others. She may make friends with

One teacher concluded that the way she liked to use her personal journal would be the way that she would expect her students to use it: "I think Im going to like this dialogue journal! There is so much going on in class that I find it very comfortatile to retash edch dity. "On journal use with her kindergarten and firstgrade students, she wrote:

I think this dialogue journal is going to be interesting with my little ones. I think my direction is going to be a period toward the end of the day when they can rethink the: day and write or daw some of the importart things they thought of cluring the day.

Application of shared mutuality approach in journals. In these joumals, teachers responded in rather tradi tional stereotypical. teacher directed ways regardless of whether they were doing so in the role of teacher or of student. Staton at al (1988) stated that one benefit of using dialogue joumals with students was lhat it allowexl a deviation from the traditional power inbalance between leacher and student. Teachers in this sample. houever. semed to maintain the traditional imbalance. The discourse functions most heavily utilized by all teatchers in this sample were also typical of controlling teaching behaviors refortins upirions, evaluating, reporting general facts, and requesting opinions. In response to a fifth-grade fenale who had apologized for her behavior in class the previous day and promised to try to be better, the teacher said:

That s all you cam do is lry, but really try to setlle down.

You are doing such a greal iob on vour architecture model. I believe when you settle down a little more, you can finish way ahead.

The functions that teachers used least with their students were the very one? which one would expect fo find between equal partners engaged in conversation. As colleagues might exchange feelings in a conversation, the teachers, in responding as graduate students, often complained, apologized, or reruested procedures. Howewer, none complated to their students. and only four teachers apologized or asked for procedures from their stikents. Teachers did, however. respond respectully to stadents who did. A reluming fourb-grade slualext in'reste.

Today was the first day of computers. I have been mean ing to say this for at least 2 years but we didnit wrile joumals then. I think kicls who know about computers shouldn't have to do all the stuff they already know. P.S If it's possible, show this to the computer teacher].

The teacher responded by acknowledging the concern, taking action, offering some "teacher" perspective, and finally thanking the student for airing the concern

1 bet it's frusirating for you to sit and lister when you already know il. I will bring your feelings to lcomputer teacher and program director]. I think [computer teacher] just has to be absolutely sure that everyone knows. Thanks for staring with me.

Responses reflect individual differences among teachers. Al teachers evaluated and reported opinions and general facts to most or all of their students. Beyond the common use of those three discourse functions, however, teachers seern to have responded individually to the students since no other discourse function was used by all teachers wilh ail of their students. For example, although all leachers requested opinions from some students in each class, only four did so from all the stufents within that class.

Table 1

Study 1: Individual Differences in the Flexibility of Teacher Responses to GT Students

\begin{tabular}{|c|c|c|c|c|}
\hline & $\begin{array}{c}\text { Stu } \\
0\end{array}$ & $\begin{array}{l}\text { Juml } \\
\text { Jou }\end{array}$ & $\begin{array}{r}\text { of } \mathrm{G} \\
\text { als P } \\
3-4\end{array}$ & $\begin{array}{r}\text { Class } \\
5-6\end{array}$ \\
\hline \multicolumn{5}{|l|}{ Shuy Discourse F unctions } \\
\hline Reporting opirions & 0 & 0 & 0 & 11 \\
\hline Reporting personal facls & 2 & 5 & $?$ & 2 \\
\hline Reporting general facts & 1. & 1 & 2 & 7 \\
\hline Responding to questions & 3 & 3 & 4 & 1 \\
\hline Predictirsg & 4 & 3 & 4 & 0 \\
\hline Complaining & 11 & 0 & 0 & 0 \\
\hline Giving directives & 2 & 3 & 1 & 2 \\
\hline Apologizing & 7 & 3 & 1 & 0 \\
\hline Thanking & 3 & 5 & 1 & 2 \\
\hline Evaluating & 0 & 0 & 0 & $1 \overline{1}$ \\
\hline Offering & 2 & 1 & 7 & 1 \\
\hline Promistrg & 2 & 3 & 5 & 1 \\
\hline Question asking & 2 & 3 & 2 & 4 \\
\hline Requests for information & 2 & 3 & 2 & 4 \\
\hline Requests for procedures & 7 & 3 & 1 & 0 \\
\hline Requests for opinions & 0 & 3 & 3 & 5 \\
\hline
\end{tabular}

Note. lor each of the 11 teachers a stratified random sample balanced for gender and grade level was analyzed. Resilts are shown as the number of leachers using that discourse function with the number of students indicated.

There was some interesting variance among the other discourse functions in the teacher responses: orly thee leachers shared personal facts with all students in their class; two did so with some of their students, and six seldom did. There did not appear to be a relationship between the sludenl's aye and the teacher's willingness to share personal information since some teachers of primary and some of intemediate students chose to share. 
Similarities of response patterns between teachers and their students. The content of the juurnals teachers wrote in their role as students was quite similar to thal written by the elementary and middle school students. For example, a fourth-grade student wrote:

The first thing I thought when I came in the room was that ididn t know anyih ing alsout this class and everyone else did. But it turned out quite differently. I think I am. going to like it here.

A teacher wrote in her own journal:

Day 1: There goes my summer! I sure hope you are going to make me feel ok. Right now my stomach has a few butterflies.

Day 2: Well I thin l ve figured out where I want to be in 2.1/2 weeks [enct of seminar]. I now feel like I am on the right course.

Another teacher acknowledged her concerns but began to address them as she continued to write:

OK Iil contess-secing IQ scores higher than mine really scares me (terrifies). I mean, can I, mere mortal, sitmilate these kids in ways others haven't?

It is an awesome responsibility. I like the topic areas I've self-selected I am also interested to find many farniliar names in the class of kids l've had over the years.

To have elicited such openness, this researcher as instructor surely must have leveled the playing field of instruction. I lowever, the analysis of the instructor's own responses to the graduate students revealed that her most frequerenty used discourse functions were the same traditional responses as those the graduate students hat used when they had been in the role of teacher: evaluating, reporting opinions. responding to questions, and giving getretal facts. The instructor dis model broad use of the discourse funclions by using 15 of the 16 language functions, which was more than all but one of the graduate student teachers had in any of their journal responses. Like her students when they were in the role of teachers, the instructor never complaind to her students. Thus the instructor, who philosophically believed in a collegial dpproach to leaming. had not spontameously nodeled it in her journal responses. even with age peers; role behavior dominated.

\section{Conclusions}

The nature and type of responses teachers used in their own journals and with their students demonstrated clearly that they both used and encouraged their students to use key elements of the dichoune journal process: self-gerenated. interactive, and functional use of language to communicate on a wide variety of topics. The types of discourse functions most used by studenls and by teachers, however. were consistent with thoses one would expect lo find in interaction among teachers and students who were behaving in ways their tradi tional roles suggest.

In their own evaludion of the journaling process, teachers feth that the dialougle joumals were valuable because they were enjoyable, served as a good source for giving and getting ideas, and allowed them to personalize instruction in both the corgnitive and affective domains. 'They strongly endorsed using dialogue journals, but some were concemed atyut how one could maintain the process over time with more students. So, although joumaling promoted teacher-student interaction. in many ways il was just a varianl of traditional instructional practice. Neilher teachers nor instructor spontaneously crossed traditional teacher-student roles to engage in fully collabordtive, collegial learning. Whether they could learn to do so was explured in the next study.

\section{Study 2}

Although questions cart and should be a natural part of written or oral conversation, they also typify power and control in a teaching-learning environment. Questions are the prime example of the status difference betweer student and teacher. When they are genuine, as in the Socratic method, questions help students engage complex ideas for themselves. But they can also be asked for other reasons: the ability to ask them (and elicil a response) is a primary way of showing and effecting control in a relationship. Goody (1978) states that

the use of questions in the teaching situation is struc-

tured by the fact that the teacher-pupil relalionship al-

ways tends to be defined in terms of status inequality.

with supericrity stressed as intrinsic to the teacher's role.

(p. 41)

The complex act of questioning has been the subject of much study (e.g., Bloom, 1956; Dillon, 1981; Goody. 1978; Siacks. Schegloff. \& Jefferson. 1974) by researchers who have sought to learn how to use them more effectively in the instructional process. Sanders (1966) reported that teachers spend as much as $90 \%$ of their instructional time with students asking questions. If one wants to modify the typical student-teacher interaction pattems, one must address the use of questions. Shuy (1987) reported that, in classrooms using dialogue joumals, the number of questions overall went down from $35 \%$ in class discussions to $15 \%$ in the dialogue journals. Dexir ite his belief that journaling led to what he called "shared mutuality" be?tween teachers and studer is, Shuy (1988) also reported that students responded to questions in their journals at twice the rate teachers did. Although the use of puestions diminished in the joumals in ways consistent with the concept of shared mutuality, they remained an important teacher imperalive. Since the use of questions so often inhibited shared mutuality. this study examined whether. if asked to, teachers could leam to emphasize other types of responses.

In Study 2 students were asked to give their perceptions of the lupes of journal responses they received from others and to evaluate the value they saw in jounding. This situdy also explored whelher there were differences in these opinions by genrle:r. age, or type of person with whom students exchanged the journals. Study 2 was replicated in two consecutive sum mer practica. Three fourths of the students and one half of the 
teachers maintained dialogue joumals both summers in which Stucly 2 was combucted.

\section{Method}

Subjects. Subjeds were the elementary and middle school students who met the program seledion criteria.

Study 2, year 1:

$N-147$ (54\% male. $46 \%$ female), Grades $13(15 \%)$. Grades $4-6(66 \%)$. Grades $79(19 \%)$.

Study 2, year 2 .

$N=240(6 \% \%$ male. $31 \%$ female). Grades $1-3(35 \%)$ Grades 4-6 (47\%). Grades 7-9 (18\%).

Procedure. In Study 2 leachers were shown the resulls of Study 1 arad explicitly asked to awoid the use of questions in their response's to their students by using the Shuy discourse functions (1988) as cues to assist them in varying their re sponses.

Firstyear teachers mantained three-way jounals by exchariging with a reluming teracher and their seminar inslructor throughout the o-week practicum. All teachers maintained three-way joumals with each of the 15-18 students in their class during the :3-week student program. Students maintained three-way journals by joumaling with their teacher and with a student poer in the class.

During the fircil week of the program in both summers of Study 2. students wer atked to complete a wrilter guestionnaire on the conupunets of the jounaling in which they had parlicinaled. Teachere were asked lo assist sidents with reading or writing rosponses if necessary.

Evaluation instrument. $A$ multiple-item questionnaire was developed by this rescarder based on a simila survey of preservice teachers views on maintaining dialogue journals (Schmid \& Martin, 1991). Sotmicll and Martir (1991) found that colloge sidents reported that questions were the first or second most used response from each of the three course instructors with whom they journaled.

For this study. the first sequence of questions asked elerrtentary and middle school gifted students to give their opinions atroul the value they saw in dialoxge joumating by responding to prompts using a Likert 4 point scale going from strongiy agree to sfrongly disogree. Questions included whether journal writing was fun. exsy, thard, boring; whether they liked to write, liked to yet responses, would keep a journal if no one responded, and whether joumals helped them learn. Students were then asked. again using the 4-point Likert scale. to describe the nature of the responses they recenved from others Wene the reskmisu encouraging remarts, questions. sugges tions, good idcas, kxring. interesting, helpful? Finally the studenits were astiod to comment in open ended statements on the velue of the joumating. Tley were asked to explain why

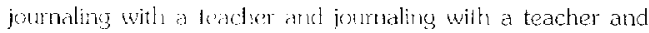
arobler silukent were botll good and bad.

Data analysis. Whivartate analyses, frequencies, $t$ - and Tukey postloc tests for the tohal sample? were calculated In addition, a three-way aralysis of variance (Year $\mathrm{x}$ Gender $\mathrm{x}$ Grade Level) irvestigated the relationships among those variables. A subset of the total sample $(n=101)$ participated in both years of Study 2. Because there were nos significant differences in the findings of the test-retest sample from those of the total sample, the findings for the total sample ( $N=387$ ) will be reported.

\section{Results and Discussion}

Studenis across both years of this study reported very positive attitudes toward maintaining dialogue joumals: $73 \%$ found journaling easy, $83 \%$ liked writing to their leachers, and $89 \%$ liked getting responses from them. The major differences between years were that during the second year more students reported liking writing to and getling responses from their teachers $(p>001)$ drk reporled that joumaling was fun $p$ $>.001)$.

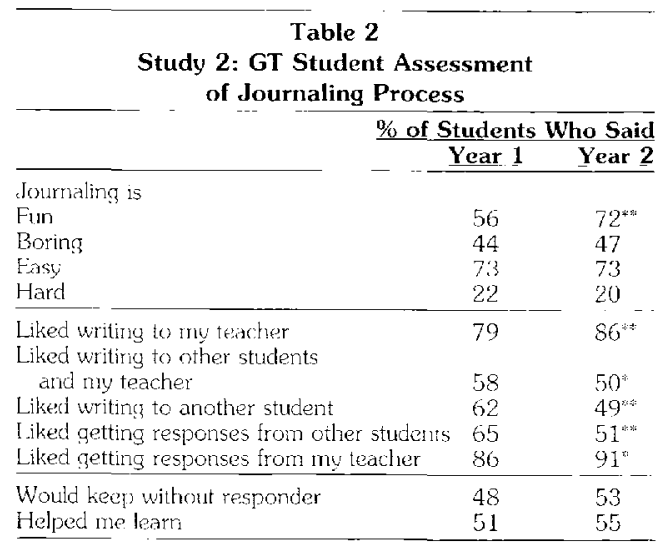

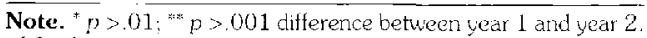
of Study 2

Questions about two-way (teacher-student) joumaling showed remarkable consistency across years, but those about threeway journaling (teacher student-student/peer) did not. Developmental and gender differences that emerged in the first year reappeared even more strongly in the second year for both topes of journaling.

Developmental differences. Significant developmental differences emerged with implications for the ways interactive writing should be used in the instuctional process. More students in Grades 1-3 reported liking two way joumaling than did students in Grades 7-9 ( $p>01$ ). Students in Grades 1-3 apparemly were not developmentally ready for three-way journaling because they were significanly less likely than the older students to report giving responses to $(p>0001)$ and getting responses from (r) >001) their peers. The youngest group commonly complained about the difficulty they had in reading their peers 
handwriting and that their peers did not have interesting ialeas to share. This niny indicate that students develop the ability to appreciate ank discrirninte among the ideas they receive from others at an earlier age than they develop the abilily to craft and communicate ideas effectively to others.

Gender differences. Gender emerged as an especially important variable both within and across years in this study. In both years, significantly more lemales than males reported finding joumal writing casy (p > 05), liking to write to other students ( $p>01$ ), liking getting responses from other students ( $p>05$ ), and liking writing to both a peer and their teacher ( $p$ $>01$ ); fernales were significantly less likely to report that the responses they received wert boring $(p>001)$. Attitudes among both genders became more pronounced the second year. Compared with the first year, significanlly more females agreed that joumal writing was easy $(p>01)$ and that they liked writing to another student $(p>01)$ and gुetting responses from that student (n) $>03$ ). Conversely, significantly more males reported findirg journaling boring $(p>001)$. These gender differences emerged agair in the types of reponses students reported getting from lheir peers. In both years. significantly more females than males foum their peers responses to be encouraging. to contain good ideas, and to be interesting; fewer fermales thought the responses they got were boring (all at $p>01$ ).

Students' perceptions of teachers' responses. The teachers in this study had been asked to minimize the ust: of questions by deliberately varying the ways in which they re. sporked to their slukents. and the students affirmed that their teachers dicl so successfully. As Table 3 shows. students were less likely to think that their wachers responses were questions than that they were the type of responses found in professional discourse anong colleagues irvolved in shared learning. Excejt for finding that their peers were more likely to make interesting responses than encouraging ones, the rank order of response types sluderls reported having gotten from their peers was identical to the rank order of response lypes they perceived they had received from their teacher. Male and female students perceived having received similar types of responses from their teachers, bit not from their peers.

Students evaluation of the journaling process. Students perceived and evaluated the use of dialogue journals in ways that were remarkably similar to the teachers resporises reported in Study 1. In their open ended responses, many students described dialogue journals as being enjoyable and a good way to communicate and learm. Students emphasized the collegial value they saw in the technique, particularly the way it promoled the giving and getting of interesting ideas. They saicl "it s good becalse she carleam from you and you can learn from your teacher," "the joumal telis Mrs. K how me and her are feeling." "it gives you a one on one basis for learring," and "il was like a conversation on paper."

Some students, like some teachers, woiced concerns about time bollt thal they did not have enough time to write and that joumaling took too much class tirne), about having difficulty in coming up with ideas or thinking the responses were not interesting, and about not liking to write or not being comfortable with sharing with others in this way. The same? students who made negative comments about two-way journaling were also likely to make them about three-way journaling.

Table 3

Comparison of GT Student Assessment of Two- and Three-Way Journal Responses

\begin{tabular}{|c|c|c|}
\hline & \multicolumn{2}{|c|}{ Type of Journaling } \\
\hline & $\begin{array}{c}\text { Two-Way } \\
\text { GT Student } \\
\text { Teacher }\end{array}$ & $\begin{array}{l}\text { Three-Way } \\
\text { GT Student/ } \\
\text { Teacher/Peer }\end{array}$ \\
\hline \multicolumn{3}{|c|}{ Percentage of Studerits Who Said Responses Were } \\
\hline Fncouraging remarks & $84(78)$ & $52(32)^{*}$ \\
\hline Interesting & $80(80)$ & $65(4.7)$ \\
\hline Good ideas & $80(77)$ & $52(38)^{:}$ \\
\hline Suggestions & $70(65)$ & $39(29)^{4}$ \\
\hline Helpful & $71(7 /)$ & $45(35)$ \\
\hline Questions & $56(61)$ & $41\{41\}$ \\
\hline Boring & $6(10)$ & $16(8)^{\prime \prime n}$ \\
\hline
\end{tabular}

Note. Data for Study 2 , vear 2 reported in parentheses adiacent to year 1 data. Differences between year 1 and year $2^{*} p>01^{1 *} p$ $>001$

Students thought that maintaining journals with peers demonstrated that they and their dissynates could communicate and provided another source of good ideas and suggestions. They appreciated the opportunity it offered to exchange views with peers whose interests. knowledge, and perspectives differed from their own, as well as with peers of similar background. They liked beiry dule lo "exrress ideas secretly" and "io make friends privately. "One student said that "it's iust like writing notes." Students described the teacher and student journals as "three-way talking," "an opjortunity to get broader views," "a way to learm how young people argee and diragree with other youry and old," and "like [beingl in their shoes." They cautioned that "students might want to share only with a peer or only with a teacher.

Comparison of two- and three-way journalingStudents' enthusiasm for maintaining dialogue journals with their teachers increased with their experience in doing it. The second year they tried it, $72 \%$ of students reported that twoway joumaling was fun, whereas the first summer, only $56 \%$ did $(p>001)$. Similarly, the percentage reporting liking to write lo their teachers increased from $79 \%$ to $86 \%(p>007)$. and the percentage reporting liking to get responses from their teachers increased from $86 \%$ to $90 \%$ in $>01$ ). Slightly more. however, found two-way jourraling boring the second year than the first year $(44 \%$ to $47 \%, p>03)$.

Three-way journaling, though, consistently got less favorable reviews from students the second year. Whereas $63 \%$ reported liking three-way journaling the first year, orly $50 \%$ 
did so the seconid year (n) > 0 1). Furthemore. they reported receiving significantly tewer and less varied responses from their pers the second vent fall $p>0$ ). A substantial change in the ase composition of the group may acoum for this finding: Grades 13 nore than doubled (to $35 \%$ from $15 \%$ ). Grades 46 declined to $47 \%$ from $66 \%$, and Grades $7-9$ dectined marginally (to $18 \%$ from $19 \%$ ).

\section{Conclusions}

These stulies found llat. under the proper conditions, interactive writing between teachers and giffed students carn indeed promote collaborative learning. Teachers do not spontaneously joumal with students in ways that are most conducive to this mode of learning: they typically respond by asking questions - a common fom of controlling behavior. When shown the proper models, however, they can learn to use discourse functions other than questions, omes thal create' an interactive, collatorative, learning envirument. Future studies might look for additional benefics of suct modeling. For example, ore might directly teach the discourse functions to bott students and teachers.

dounaling is a form of communication that is based on. and can help engender. trust. While the gifted students of all ages in this study demonstraled both that they onjoyed joumaling with their wachers and coulet effeclively participate in it, older students were more likely than younger ones to enjoy three-way joumaling with age peers. The unque relationship that emerged between student and tuadrer may have come to be increasingly valued by the students in ways that overrode the benefits of the thres-way dialogues. The linited time that the students had

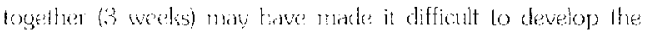
trusting relationstij] with al previously unkinown peer that theeway jomraling requires. It may also be that the increased satis faction students rorted finding in joumaling with their teachers made journaing with a little-knuwn peer pale by comparison.

Signific and gender differences merged. Althomg rot sumprising. the invite us to explore their implications for instrutetional practice. Research tells us that young female students across ability levels (Anerican Association of University Women, 1992; Stromguist 1094) and within populations of identified gifted studem (Kom, 1985: Subouik \& Arnold, 1993; Teman \& Oden, 1959, VanTassel Baska. Olszewski Kubilius. \& Kulieke, 1994) respond postively to instructional practices that emphasize personalized interactions. Although we kinw that fencale gifled sudents respond to modifying tratitional classrom protice in ways designed to appeal to females (Lictes. 1985: Kerr. 1991: Lupkowsli \& Assouline. 1992). we know lese abunt the firedivenes of these approches with maks. Cortairly we want to leam more about the benefits that the personalize format of interactive writing provides gifted

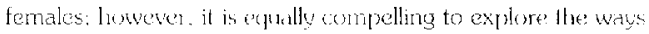
that males nighlat abo come to value the rlialogue jounal process to the extent that fendes alreaty seem to. This might entarke the statresl mulutity success, and enjoyment of kearning for all femmes and then teathers
Dialogue ioumals offer multiple potential benefis to teachers of the gited. They can foster studen-centered learning by enabling teachers to take into account students' interests and individual learning stykes by communicating to those students on both cogrilive and affective matters. These help teachers to individualize instruction, but not necessarily to promote selfdirected learning. Although one half of the teachers in this stucly identified getting personalized feedback on their teaching as the primary benefit of journaling with their course instrutor, only one thought its primary value was in eliciting feedback from students. Until teachers come to value journaling for its abilily lo promote two way communication-bolh to and from slutents-it will not fully realize its potential for promoting selfdirected learning.

Although the majority of students and teachers in this study endorsed the use of dialogue joumals, some did not. Individual differences must be considered in this as in other educational strategies. We have just begun to explore the collaborative potential of this technique for students and, more recently, for preparing teachers (Bahuth \& Howell, 1987; Canning, 1991; lrujo, 1987; Roderick, 1986; Schmidt \& Martin. 1991; Surbeck, 1 lanna, \& Moyer, 19911. As we corlinue to study the use of interactive writing in the educalional process, we should do so collaboratively. That is how we can best understand the way students and teachers will benefit rom this approach over time.

\section{References}

Alexander, P. A., \& Muia. J. A. (1982). Gifted eduction: A comprehersive roadmap. Rockville, MD: Aspen

American Assckiztion of Liniversity Women. (1992). How schools short change gir!s. Washington, DO Authot

Atwell. N. (1987). Buildiss a dini is rum tatble: Dialogue joumals about reading In T. Huwiler (Ed), The roumai book (pp. 157-170). Portsmouth, Nyt. Heiremann.

Baturuth. F., \& Howel. A. (1987). Helping studerit tenchers and teachers wilt derse attitudes. Dialogue. 4:2]. 3.

Bailes, C. Seatls S. Slotadzath, d, \& Staton, J. (1986). It's your turn now: $A$ handbook for teachers of deaf students. Washington, $\mathrm{DC}$. Gallandet Universily Press

Bloom, B. (1956). Taxonom of educational objectives. New York: Longharn. Green.

bole. B. (1989). Dralogue joumal writing. The Recding Tear her, 42, $568-571$.

Boutinghouse A. (1984). What s your style? A learning style inventory for lower elenteritary grades. Koeper Heniew, 6, 208-210.

Bruner, J. (1978). The role of dialogue in language acquisition. In A. Sinclair. R. Jarvella, \& W. I evant (I.ds) The chidd's conception (p? 241-256). New York: Springer.

Canning. C (1991). What teachers say abuut reflection. Educationa' Leadershir. 48, 18-21

Corland. J. (1981). School success of gifted Appatachian youth and thein percegtions of parental attittide: toward acadentic success. Disserta tion Abstracis International, $42(10 \mathrm{Nj}, 4360$

Carto. L. (1987). Dialogue joumals Caradian Journal of Native Eduartion. $14(2) .54 .59$

Danielson. K. (1988). Dialogue jotimals: Witing as combersation. Fastbacki \# 266. Blomington. IN: Phi Delta Kappa

Dearbon. P. (1979). Will you come alla joir the datce Ar invitation to gified writers Journul for the Edwation of the Gifted. 2. 173-180

Dilkn. T. (1931). To question or not to question Enmai of English Exlucation. 32, 15-20

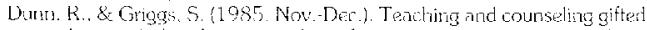
students witin their learning style prefarences: Two case studies. GC.T (No . 1), 40-43. 


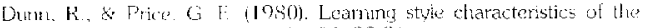

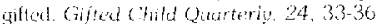

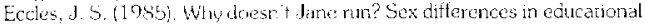
and occupational patterns. In F. D. I Iorowitz \& M. O. O'Brien (Eds.) 7he gifled and talented. Developmental perspertiles (pp. 25.3295). Wablugan, D): Ancrican Psychological Asociation.

Farley. d. (1985). An andusis of foumal writina abilities of a groun of

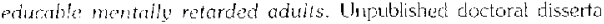

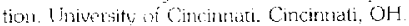

Follay, I., \& Furlou. 5. (1987). Interactive uriting and gifted children Commeniminn Horegh literacy. Joumal for the Educotion of the Gifted 10.94106

Froelill, M. F. (1982). Gifted rhildren: Their pswchology and education Ventura. CA: Ventuta County Superintendent of Schools tor the National State Lodulustip Troining Institute for the Gifted and Talented.

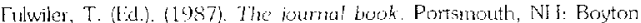
Cook.

Ganbrell 1. (1985. Dintugue journals: Reading writing interaction Read ing 7 iocher, $38,512.515$.

Garcia, $\mathrm{F}$, (1990). The effect of teacher reaction on students interactive joumal entries. Eurly Child Denclopment and Care: 56, 35-17

Gaustad. M., \& Mraseriteiner Young. T. (1991). Dialogue journals for students with learnima dimbilities. Traching Fxcentionai Chidren. 3. $28-32$.

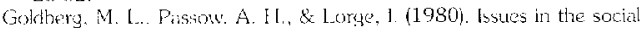
edication of the acialenically talented.

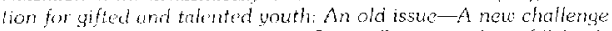
(10. 4559) Ventura. CA. Ventura County Superintendent of Schouls for the Vaticinal/state Leadership Trairing Institute for the Gifted and Talentid

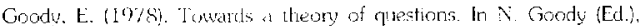
Questions and politeress: Sirulegies it social interwention (pp. 1743). Cannluidoe. (IK: Cambridge Unives sity Press.

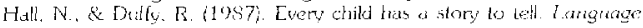
Art5, 64. 52, $-5,29$.

1 larty. I I. Adkin, I) \& Hingate, E. (1984). Exploning self-cuncept and loct of amolol if student in two recognized approaches to eleneruary

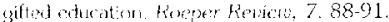

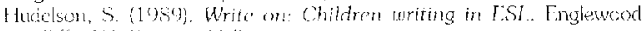
Chits, Nif: l'rentice toill.

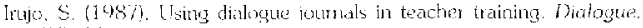
$4: 2 ! 11$.

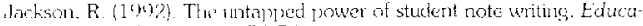
rionod Iodidersing. 49, 54-58.

deter, J. Che Chivin J.C. (1982) Individualized instruetion: Implications for the gifled Rate" Revich. 5. 2-3.

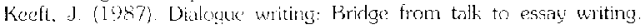
Language Aris. 61, 111-150

Kotr. B. (1985). Simant giris. gifted woner Columbus, OH: Onio Psucholugy Prasis.

Kert, B. (1991). Edueoting gifted girls. In N. Colangelo \& G. A. Iavis

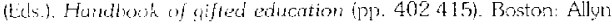
aId Uaral:

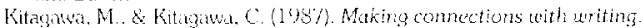

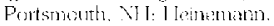

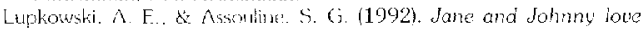

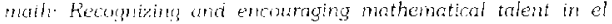
cmentery students, Uniouville. NY: Trillinm.

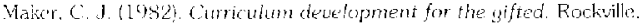
MD: Npeti.

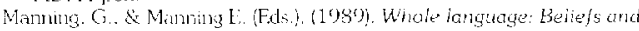

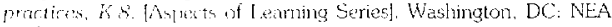
Prentessignati litiand

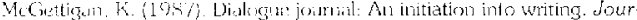

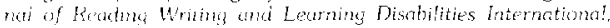
3(1). $321-332$

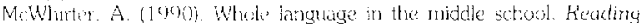

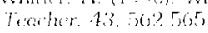

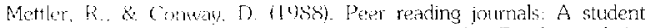

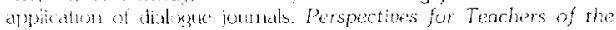
Hearisg throtiria $7(1), 20-22$.

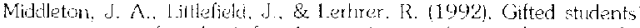
corceptions of acadernic furn: Ar exan nimation of a critical construct for gifled education. Gifted Child Quarteriv. 36. 38-44.

Milgram, N. A., \& Milgram, R. M. (1975). Dimensions of locus se control in children. Pswchologica! Reports. 37. 523,538

Migram, R. M., \& Milgram, N. A. (1976). Personality charnctaristics of gitted Jsmali children douma! of Genetic Psucholoty 129, 185-194.

Pascou'. A. I I. (1979). A look around and a lock ahead. In A. H. Hassow (Id.). The gified and talented: Their educition and development. Senentu-einhth vearbook of the National Association for the Study of Education: Part l (pp, 439-456). Cticago: Uriversity of Chicago Press

Perrone, '.. \& Mak, R. (1981). The devolopmental education and guidance of talented learners. Rockville. MD: Aspen.

Feylon, J. (1990). The influence of writirg task or ESL students witten production. Research in the Teaching of English. 24(2). 142171

Feyton, d. \& Seyoum. M. (1989). The effect of teachers strategies on interartive writing: The case of dialogue jounals. Feseorch in the Teaching of Finglish, 2.3(3), 310 3.34

Price G. (1981). Studies in students' leaminu stutes. Rocper Revicu. 1 , 38.40

Feed. L. (1986). Dialogue journals make my year flow: The teacher's perspective. In d. Staton, R. Shuy, J. Peyton, \& I. Reed (Eds) Dialogue jounal communication. Classroon lingustir social and cognitite views (p. 56-72). Nonvood. Nit Ablex.

Roderick, d (1986). Dialoguse writing: Context for reflecting on self as teacher and researcher, Journal of Curricuran and Superuision. 14i4) $305-315$

Rodetick, J. \& Berman. 1 (1984). Dialuguing about dialosue foumals. Langugae Arts, 61, 686-692.

Sacks, H. Schegloff. E., \& Jefterson, C. (1974). A simplest systematics for the organization of turn-taking for comversation. Longuage. 50 . $696-735$.

Sanders, N. (1966). Classroom questions: What kinds? New York: I Inrper and Row.

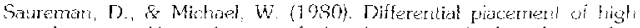
achieving and low achieving gifted students in urdes four five and six on meatsures of fidd dependence and fiesd inderpendence. cribalivity and self-concert. Gified Cintid Quarterly. 21, $81-86$.

Schmidt. M. \& Martin, B. (1991). Journal we in preservice education. Freservice teachers perspectives. New Orleans I A. Assoriation of Teacher Fitucators.

5ruggs, T \& Mastropieri, M. (1984). I low gifted students lean: Implia tions from recent research. Roeper heview, $6,183-185$

Shor, L. \& Freire, P. (198\%). A pedagogy Jor iberation: Lialogues for trams/ormme education. Suth 1 lades. MA: Bergin and Garey

Shore. B. M. Comeli. D. G. Robinson. A. \& Ward. V. 1991). Recom mended practices in gifted education: A ritical andysis. New York Teachers College Press

Sinuy. R. (1987). Reseanch curents: Dialogue as the teant of henring Languane Arts, 64, 890-897

Shu, R. (1983). Sentence level language furcions. In d. Staton, F. Shet J. Peyton. 8x L. Reed (Eds). Dialogue joumai conmunication Class room linguistic sociai, and cognitue neese (pp. 107 142). Norwood. Nit: Nbtex

Statin. J. (1980). Writing and courseling using larguage arts. Language Arts $57,511-518$

Staton, J (1985). Using dialogue joumals for developing reading. thit thing. writing with hearing inpaired students, Voita Revieu, 87(5). 12\% 154

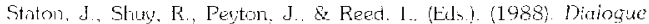

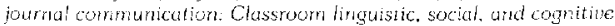
views. Nonuood. Ni: Ablex.

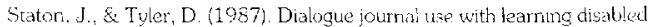
students Pointer, 32(1), 4-8.

Stewart. Г. Г. (1981). [ eaming styes anong gited forentad students: 1.structional techrique preferences. Fxceptional Chila, 482, 1.34-138.

Stromquist, N. P. (1994) Sex-eguty legistation in eduction: The state as pronoter of women s rights. Review of Educationa! Research. 63(4). $379-407$.

Subotrik, R., \& Arrold K. (1993). Beuond Teman: Iongitudinai stud jes ir contemporary gifted education. Nomwed N. Ablex 


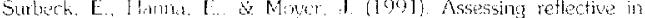

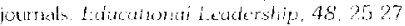

Terman, L. M. \& Oden, M. H. (1959) The gifted group w mid-tife Stantord. CA: Stanthed lle liversily l'sess

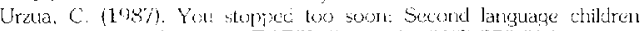
coniposing and wising TOFSL Quarterly, $21(2) 270304$

VanTassel-13aska. J. Ol zowsila Kubilus. P. \& Kulieke, M. (1994). A study of salf-concont and social suphort in advantaged and disadvantaged suvert and eighth grade giffed students. Foaper Renien, 16. $186-191$
Vyootsky, L. 11962). Thought and langtoge (C. Handeram \& G Backe Trans.). Canturidge, MA: M.I.T. Press

Vysotsiy. I. (1978). Mind in sociely. The develomment of higher psuchological processes. (R. Louberman. Ed. \& Trans.). Cambridge. MA: liarvaril University P'ress

Whitmore, J R. (1986). Understanding a lack of motiwation to exrel. Gifted Child Quarterly, 30. 66-69

Yuriz. F. L. (1991) Self-concepts, locus of control, and Machiavellianism of ethnically diverse middle school students who are gifted. Roeper Revicw. 16, 192194.

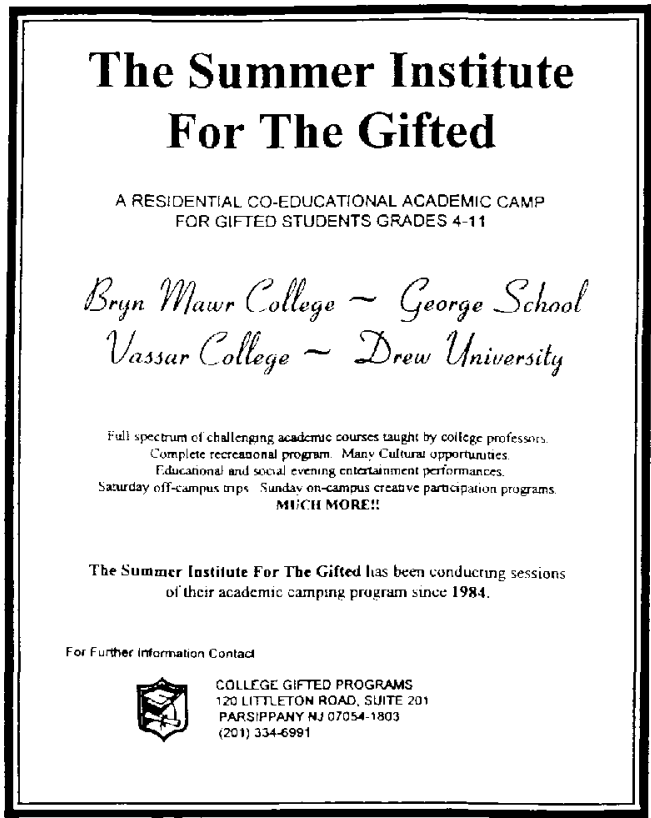

